\title{
PEPTIDASES IN HUMAN SERUM: A COMPARISON OF ACTIVI- TIES BETWEEN NORMAL PERSONS AND PATIENTS WITH LIVER DISEASES AND OTHER PATHOLOGIC CONDITIONS
}

\author{
BY GERARD A. FLEISHER AND HUGH R. BUTT \\ WITH THE TECHNICAL ASSISTANCE OF NORMA GOPLERUD \\ (From the Section of Biochemistry, Mayo Foundation, and Division of Medicine, Mayo Clinic, \\ Rochester, Minnesota)
}

(Submitted for publication March 2, 1953; accepted April 2, 1953)

The existence in normal human serum of enzymes belonging to the group of peptidases has been well established in recent years. Grassmann and Heyde (1) first described the hydrolysis of L-leucylglycylglycine (LGG) and L-leucylglycine (LG) by the serums of different species, including man, and attributed these effects to two rather nonspecific enzymes, one a polypeptidase and the other a dipeptidase. Because of the number of different enzymes which have been isolated in re- cent years from animal tissues (2), it is now generally believed that serum may also contain several peptidases distinguishable by their different specificity patterns.

In most recent investigations the hydrolysis of LGG by serum was compared between normal persons and patients with a variety of diseases. As pointed out by Smith (3), this peptide is particularly ill-suited as a substrate, since it may be attacked by leucine aminopeptidase as well as by

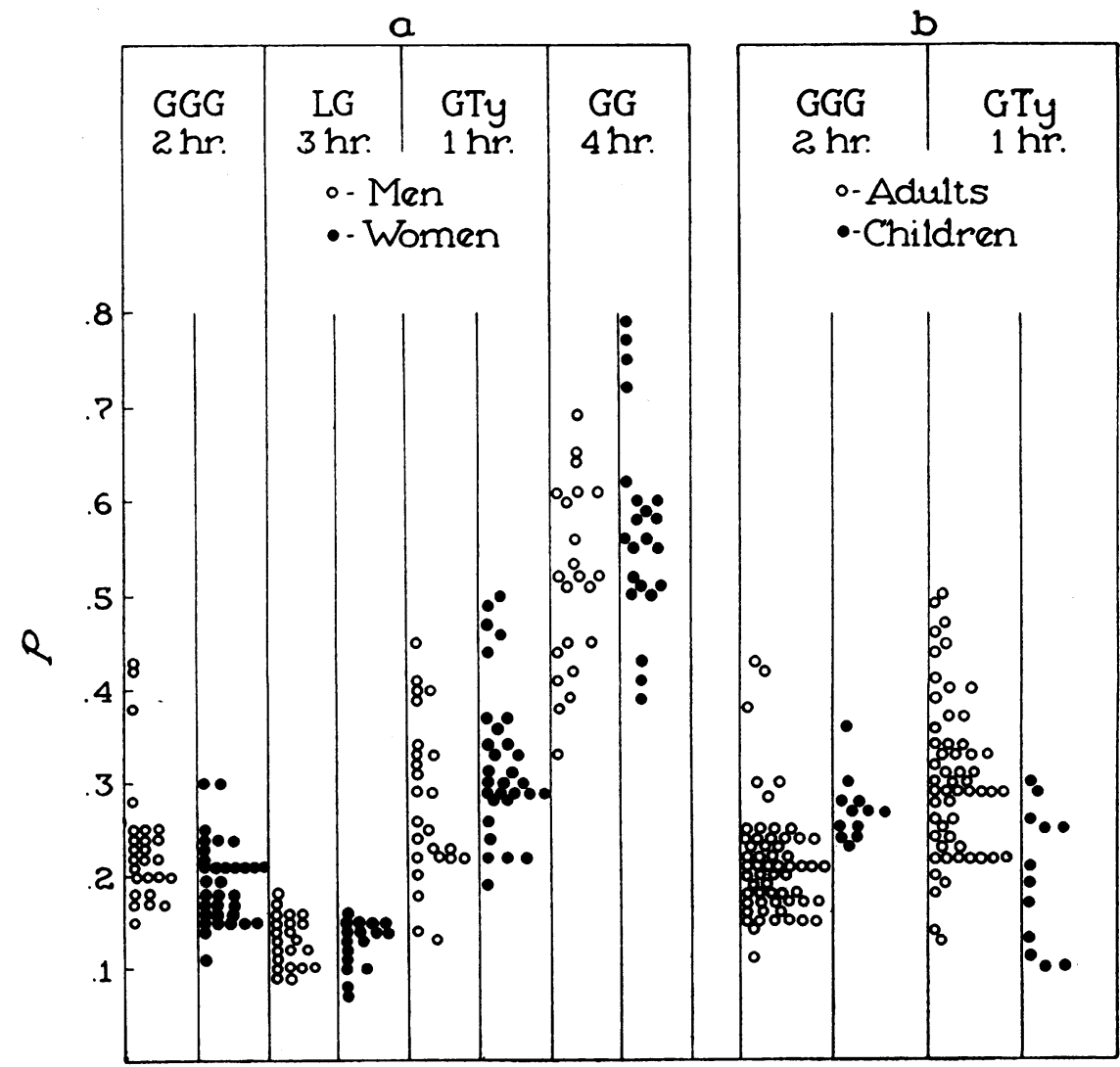

Fig. 1. Comparison of Normal Serula Peptidase Activities between $a$, Men and Women ; $b$, Adults and Children 
tripeptidase, both of which appear to be present in human serum. A further complication has often been introduced through the use of cobalt ion which, because of activation of the glycylglycinesplitting enzyme, will cause hydrolysis of the second peptide bond of the tripeptide, in addition to the first. Thus, an increased rate of LGG-hydrolysis in pathologic conditions, as compared with the normal range, may not necessarily indicate an increased tripeptidase activity. The rate of hydrolysis of LGG (or other tripeptides, as indicated) has been reported to be increased in fever (1); fractures $(1,4)$; lymphatic leukemia, pneumonia, acute rheumatic fever, hypertension, acute barbiturate intoxication (5); lupus erythematosus (with alanylglycylglycine) (6); and in part of the cases of cancer $(1,5)$; tuberculosis, asthma $(5)$; and acute hemolytic anemia (with glycylglycylglycine) (7).

The present study was undertaken to compare the hydrolysis of four peptides by serum of a group of normal controls with that of a number of patients suffering from a variety of diseases, especially of the liver.

\section{MATERIALS AND METHODS}

While no significant change in peptidase activity could be found after a meal (8), fasting blood was used almost exclusively. It was drawn from the cubital vein, and the serum was separated by centrifugation as soon as clotting was complete. The serum was either used immediately or kept frozen at $-18^{\circ} \mathrm{C}$. for periods up to two weeks. The freezing had no deleterious effect on the enzyme activities.

Four commercially available peptides were used as substrates. They were glycyl-L-tyrosine (GTy), L-leucylglycine (LG), glycylglycine (GG) and glycylglycylglycine (GGG); their final concentration was $5 \times 10^{-8} \mathrm{M}$. The buffer system was uniformly $0.06 \mathrm{M}$ veronal-veronal sodium of $\mathrm{pH} 8.0$ (9), which is at or very near the peak of the dipeptidase activities (8). The optimal condition for the tripeptidase of normal serum is approximately at $\mathrm{pH} 7$ (10); however, it was found that in certain diseases, the activity at $\mathrm{pH} 8.0$ is increased more than that at $\mathrm{pH} 7.0$ (8), which has justified the use of one buffer for all four reactions. As shown by other workers (11,

TABLE I

Summary of data of patients with liver disease

\begin{tabular}{|c|c|c|c|c|c|c|c|c|c|c|}
\hline Patient & $\begin{array}{l}\text { Age } \\
\text { and } \\
\text { sex }\end{array}$ & $\begin{array}{c}\text { Ascites, } \\
\text { grade } \\
0-4\end{array}$ & $\begin{array}{c}\text { Liver, } \\
\mathrm{cm} .\end{array}$ & $\begin{array}{c}\text { Spleen, } \\
\text { cm. }\end{array}$ & $\begin{array}{c}\text { Total } \\
\text { bilirubin, } \\
\text { mg. per cent }\end{array}$ & $\begin{array}{c}\text { BSP } \\
\text { retention, } \\
\text { per cent }\end{array}$ & $\begin{array}{c}\text { Thymol } \\
\text { turbidity }\end{array}$ & $\begin{array}{c}\text { Cephalin } \\
\text { floccu- } \\
\text { lation } \\
\end{array}$ & $\begin{array}{c}\text { Alkaline } \\
\text { phospha- } \\
\text { tase }\end{array}$ & Diagnosis \\
\hline $\begin{array}{r}3 \\
9 \\
10 \\
14 \\
17 \\
19 \\
21 \\
23 \\
34 \\
39 \\
43 \\
44 \\
53 \\
29 \\
15 \\
24 \\
26 \\
31 \\
33 \\
32 \\
6 \\
20 \\
45 \\
46 \\
56 \\
47 \\
25 \\
27 \\
28 \\
30 \\
55 \\
22 \\
48\end{array}$ & $\begin{array}{l}45 \mathrm{M} \\
54 \mathrm{M} \\
64 \mathrm{M} \\
61 \mathrm{M} \\
70 \mathrm{M} \\
53 \mathrm{M} \\
35 \mathrm{~F} \\
41 \mathrm{M} \\
45 \mathrm{M} \\
53 \mathrm{M} \\
36 \mathrm{M} \\
42 \mathrm{M} \\
59 \mathrm{M} \\
27 \mathrm{M} \\
53 \mathrm{~F} \\
73 \mathrm{~F} \\
52 \mathrm{M} \\
43 \mathrm{M} \\
50 \mathrm{M} \\
40 \mathrm{M} \\
52 \mathrm{~F} \\
76 \mathrm{M} \\
69 \mathrm{M} \\
57 \mathrm{M} \\
25 \mathrm{~F} \\
31 \mathrm{M} \\
59 \mathrm{M} \\
49 \mathrm{M} \\
36 \mathrm{~F} \\
63 \mathrm{M} \\
50 \mathrm{M} \\
38 \mathrm{~F} \\
47 \mathrm{~F}\end{array}$ & $\begin{array}{l}3 \\
1 \\
0 \\
0 \\
0 \\
3 \\
2 \\
1 \\
4 \\
2 \\
0 \\
0 \\
0 \\
0 \\
0 \\
2 \\
0 \\
0 \\
2 \\
1 \\
0 \\
0 \\
2 \\
0 \\
0 \\
0 \\
0 \\
0 \\
1 \\
0 \\
0 \\
0 \\
0\end{array}$ & $\begin{array}{r}5 \\
10 \\
8 \\
6 \\
0 \\
3 \\
8 \\
5 \\
0 \\
0 \\
6 \\
9 \\
6 \\
4 \\
0 \\
8 \\
10 \\
5 \\
9 \\
8 \\
0 \\
0 \\
2 \\
3 \\
3 \\
10 \\
6 \\
5 \\
3 \\
3 \\
0 \\
6 \\
4\end{array}$ & $\begin{array}{l}0 \\
0 \\
0 \\
3 \\
0 \\
3 \\
6 \\
0 \\
0 \\
0 \\
0 \\
0 \\
4 \\
2 \\
0 \\
0 \\
4 \\
0 \\
5 \\
0 \\
0 \\
0 \\
0 \\
0 \\
0 \\
0 \\
0 \\
0 \\
0 \\
0 \\
0 \\
2 \\
0\end{array}$ & $\begin{array}{r}1.6 \\
1.7 \\
1.0 \\
1.7 \\
3.6 \\
1.7 \\
3.5 \\
5.5 \\
1.8 \\
1.5 \\
1.3 \\
2.2 \\
1.2 \\
8.2 \\
6.8 \\
1.7 \\
15.6 \\
12.9 \\
23.8 \\
0.7 \\
4.4 \\
20.2 \\
17.8 \\
20.1 \\
14.0 \\
14.4 \\
6.0 \\
18.4 \\
6.6 \\
19.4 \\
5.1 \\
23.9 \\
2.1\end{array}$ & $\begin{array}{l}24 \\
30 \\
14 \\
16 \\
40 \\
40 \\
22 \\
\frac{20}{32} \\
10 \\
32 \\
32 \\
0 \\
26 \\
= \\
\overline{2} \\
20 \\
= \\
= \\
= \\
= \\
\bar{Z} \\
= \\
\bar{Z}\end{array}$ & $\begin{array}{c}5 \\
= \\
5 \\
1 \\
= \\
15 \\
7 \\
= \\
= \\
72 \\
5 \\
8 \\
3 \\
4 \\
2 \\
4 \\
5 \\
9 \\
12 \\
5 \\
4 \\
2 \\
\frac{1}{2} \\
2 \\
2 \\
1 \\
4 \\
2.5\end{array}$ & 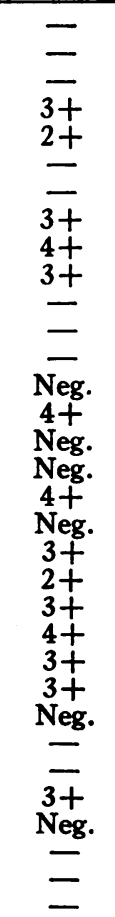 & $\begin{array}{c}\bar{Z} \\
\bar{Z} \\
3.8 \\
\bar{Z} \\
10.8 \\
2.7 \\
\bar{Z} \\
\bar{Z} \\
\overline{7} \\
7.3 \\
32.6 \\
7.6 \\
18.4 \\
9.1 \\
4.6 \\
6.6 \\
4.6 \\
6.6 \\
3.3 \\
96.7 \\
\overline{6} \\
37.5 \\
15.2 \\
13.6 \\
52.9 \\
26.4\end{array}$ & $\begin{array}{l}\text { Cirrhosis } \\
\text { Cirrhosis } \\
\text { Cirrhosis } \\
\text { Cirrhosis } \\
\text { Cirrhosis } \\
\text { Cirhosis } \\
\text { Cirrhosis } \\
\text { Cirrhosis } \\
\text { Cirrhosis } \\
\text { Cirrhosis } \\
\text { Cirrhosis } \\
\text { Cirrhosis } \\
\text { Cirrhosis } \\
\text { Cirrhosis } \\
\text { Post. nec. cirr. } \\
\text { Biliary cirr. } \\
\text { Biliary cirr. } \\
\text { Biliary cirr. } \\
\text { Biliary cirr. } \\
\text { Biliary cirr. } \\
\text { Inf. hep. } \\
\text { Inf. hep. } \\
\text { Inf. hep. } \\
\text { Inf. hep. } \\
\text { Inf. hep. } \\
\text { Ca. head panc. } \\
\text { Ca. head panc. } \\
\text { Ca. head panc. } \\
\text { Ca. head panc. } \\
\text { Ca. head panc. } \\
\text { Ca. head panc. } \\
\text { C.d. stricture } \\
\text { C.d. stricture }\end{array}$ \\
\hline
\end{tabular}




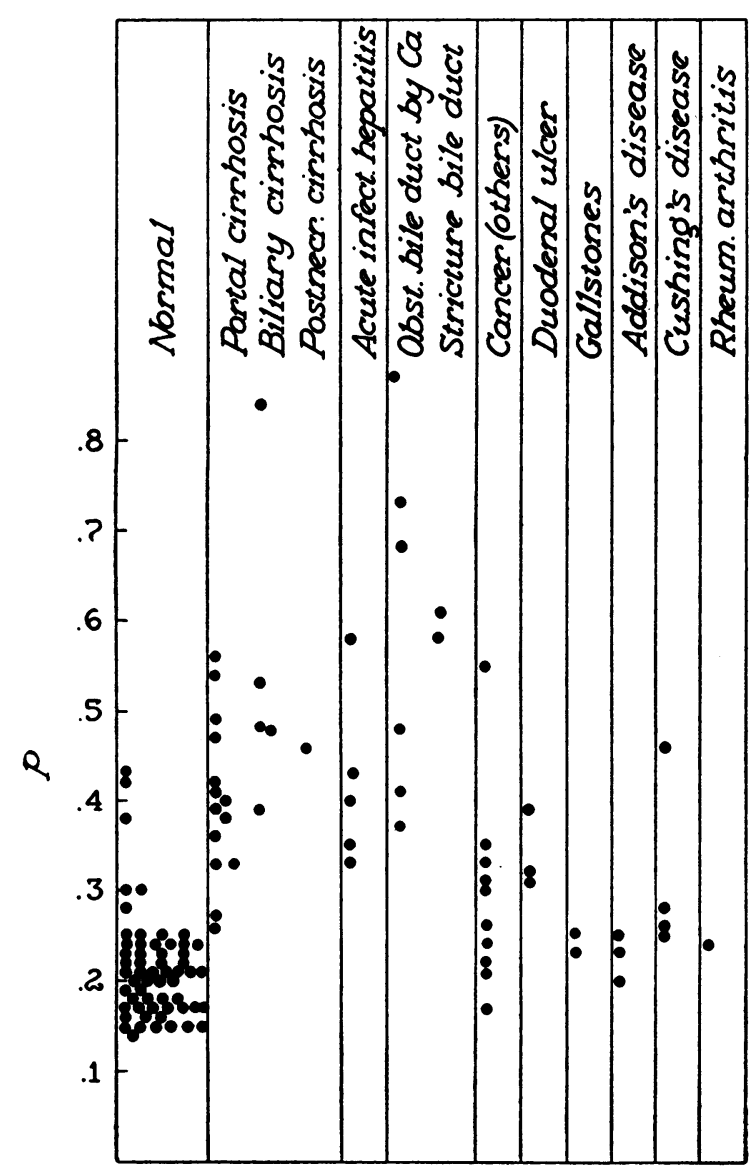

Fig. 2. Comparison of Serum Tripeptidase (GGG) between Normal Controls and Patients Suffering FROM A VARIETY OF Diseases

12), the tripeptidase is active without any ion added, while the enzyme acting on LG requires manganese $(11,12)$ (the same applies to the one acting on GTy), and the dipeptidase which hydrolyzes GG has to be activated by cobalt $(12,13)$. The activation of peptidases by manganese has generally been found to be a slow reaction (2), and this is true also for the enzymes in serum which act on LG and GTy (8). For this reason, serum was first incubated with manganese chloride in the absence of LG and GTy. For each milliliter of serum, $0.5 \mathrm{ml}$. of $0.1 \mathrm{M}$ veronal buffer and $0.1 \mathrm{ml}$. of $0.1 \mathrm{M} \mathrm{MnCl}_{2}$ were used. After two hours at $38^{\circ} \mathrm{C}$., an additional $2.4 \mathrm{ml}$. buffer and then $1.0 \mathrm{ml}$. of $25 \times 10^{-8} \mathrm{M}$ LG or GTy were added to start the reaction. The final concentration of manganese was, therefore, $2 \times 10^{-3} \mathrm{M}$. Because the activation of the GGsplitting enzyme by cobalt ion appeared to be immediate, a preliminary incubation of serum with cobalt was omitted. The final concentration of $\mathrm{CoCl}_{2}$ was $10^{-3} \mathrm{M}$.

Hydrolysis was measured by the colorimetric ninhydrin method of Moore and Stein (14), as applied to peptidase reactions by Schwartz and Engel (15). Because of the smaller substrate concentration used by us, $0.5 \mathrm{ml}$. sam- ples of the reaction mixtures were removed for analysis and precipitated with $2.0 \mathrm{ml}$. of 1 per cent picric acid solution. The further experimental details were identical with the method of Schwartz and Engel, except that a L-leucine solution of $5 \times 10^{-4}$ molarity, corresponding to $0.1 \mu$ mole per determination, was used as a reference standard, and corrections were applied to the observed optical densities corresponding to their deviations from Beer's law. Details of this procedure will be described elsewhere (8). The corrected densities were converted to the fractions $\mathbf{p}$ of the original substrate concentration which have reacted in the various time intervals. (We prefer to base our calculations on unit substrate concentration rather than on 100 per cent, in order to have a general basis for kinetic considerations.)

A quantitative comparison of p-values can, of course, be made only if a reaction follows zero-order kinetics. This is not true for the tripeptidase, nor does it hold for the other enzymes under the experimental conditions used here; on the other hand, the reactions cannot be adequately described by first-order equations either.

Because of its complex nature, the kinetics of these reactions will be treated in a separate publication (8). In this paper the experimental results will be reported only as the p-values obtained after a fixed time of incubation for each substrate. This was arbitrarily chosen as one hour for GTy, two hours for GGG, three hours for LG and four hours for GG. The findings in the serum of

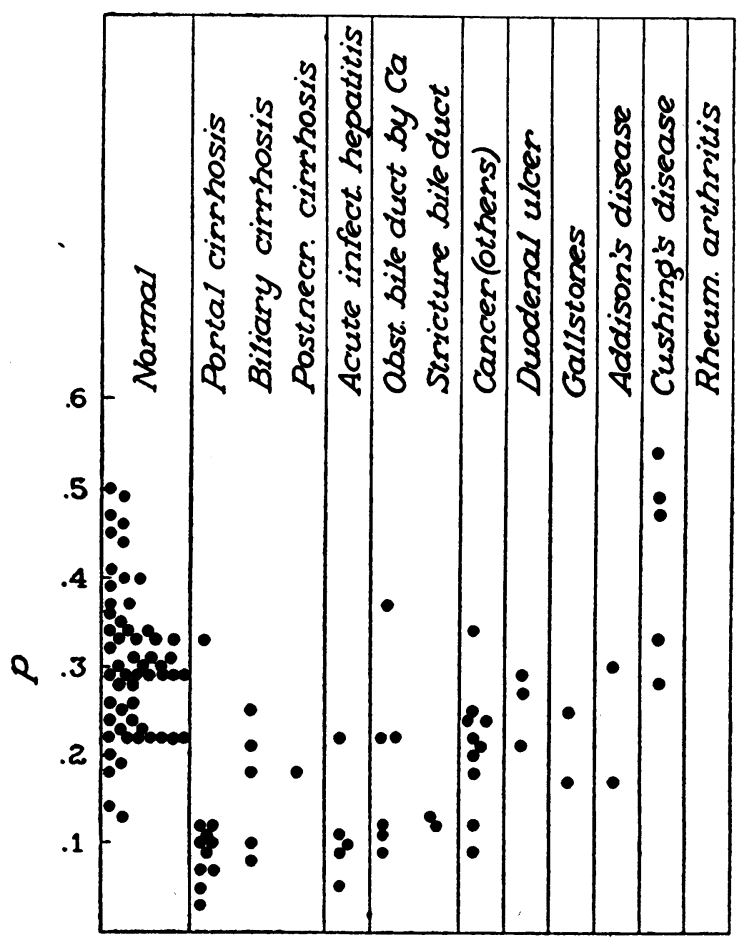

Fig. 3. COMParison of GTY-HYDROLYZING ACtivity in Seruy between normal Controls and Patients Suffering from a VarIETy of Diseases 
different individuals will be compared semiquantitatively through the use of scattergrams. Because the kinetics of all four reactions are somewhere between zero order and first order, the statement can be made that differences which appear to be significant in the p-values would be even more so if the proper functions of $p$ were known.

The liver function tests employed were the cephalincholesterol flocculation test of Hanger (16), the thymol turbidity test according to Maclagan (17) and the sulfabromophthalein test as described by Magath (18). The serum alkaline phosphatase was determined by the method of Bodansky (19), and the serum bilirubin by the method of Powell (20).

The patients studied were all hospitalized and diagnosis in most instances was made by liver biopsy or surgical confirmation except for a few cases of portal cirrhosis in which there were obvious clinical features of the disease with ascites.

\section{RESULTS}

In Figure $1 a$ a comparison is made between the serum of normal men and that of normal women. There appears to be a slight tendency for the tripeptidase to be higher and for the GTy-splitting and GG-splitting enzymes to be lower in men than in women. If serum of children between the ages of 3 and 14 years is compared with that of adults of both sexes (Figure $1 b$ ), the tripeptidase seems to be higher and the GTy-hydrolyzing activity lower in children than in adults; however, the data are too few to allow a definite conclusion of this kind.

In Figures 2, 3 and 4 the results of an investigation on three serum peptidases in patients suffering from a variety of diseases are summarized and compared with the analyses on normal serum. The greater emphasis has been placed on liver diseases, since it was noted that in these conditions the activity of the peptidases deviates quite significantly from the normal pattern. For comparison, other pertinent data on the patients with liver disease are summarized in Table I. It will be seen that the tripeptidase activity (Figure 2 ) is increased in the majority of cases with liver injury. This effect appears to be greater in obstructive jaundice than in diseases affecting primarily the parenchymal cells. However, some elevation of the serum tripeptidase is often found in other diseases.

The data on the GTy-splitting enzyme are listed in Figure 3. It will be noted that this activity is decreased in most cases in which the tripeptidase is elevated, with the exception of the patients suf-

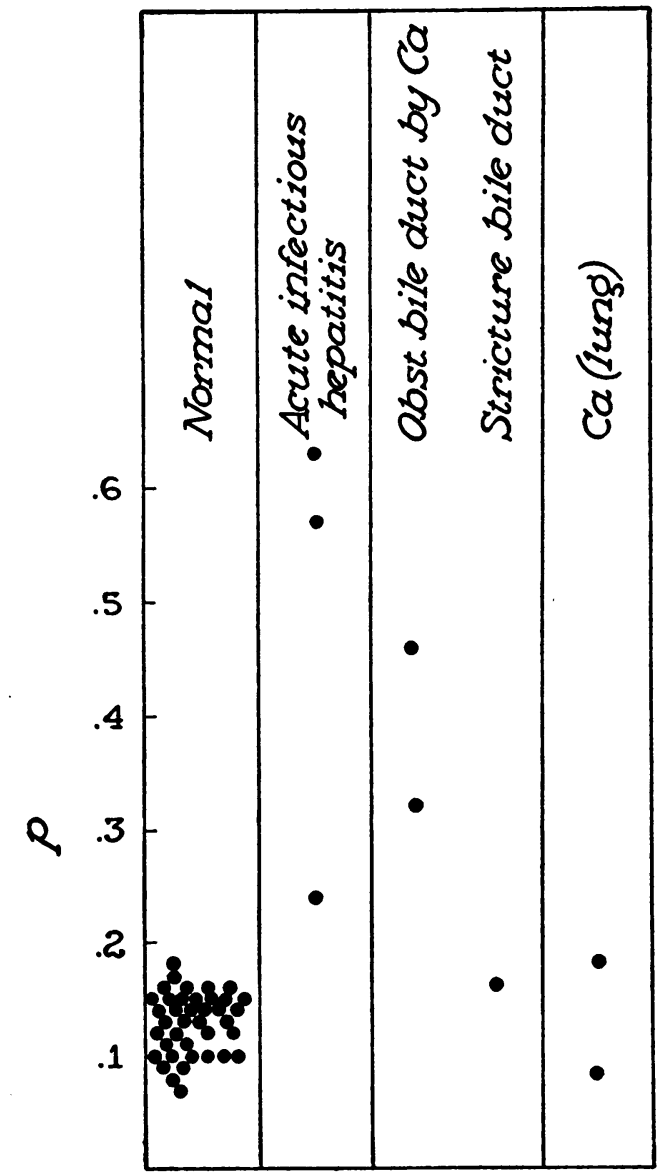

Fig. 4. Comparison of LG-hydrolyzing ACtivity in Serum between Normal Controls and Patients SufFERING FROM DISEASE

fering from Cushing's syndrome, in which both enzymes are often increased.

Data on the LG-hydrolyzing enzyme are very limited but are summarized in Figure 4.' Although in normal serum, activity of this enzyme is extremely weak, it was observed to be rather high in five of the six cases of liver disease.

A few observations on the GG-hydrolyzing activity in the serum of patients with liver disease indicate that this enzyme activity may be somewhat decreased, as compared with the normal range.

These results may indicate that the enzymes acting on GGG and LG appear to be increased in liver disease, while those hydrolyzing GTy and GG have a tendency to be decreased.

In three patients with acute infectious hepatitis, serial determinations of the serum peptidases were 
TABLE II

Peptidase activities in human bile*

\begin{tabular}{lcccc}
\hline \hline & Bile a & Bile b & $\begin{array}{c}\text { Normal } \\
\text { serum }\end{array}$ & $\begin{array}{c}0.9 \text { Serum } \\
+0.1 \text { bile b }\end{array}$ \\
\hline GGG & .590 & .725 & .211 & .249 \\
GTy & .003 & .037 & .224 & .228 \\
LG & .051 & .080 & .137 & .134 \\
GG & .171 & .227 & .408 & .394 \\
\hline
\end{tabular}

* Two different specimens were used. Specimen b was also mixed with a normal serum to test for synergism or inhibition. All figures are given as p. Conditions were the same as with serum.

performed. The results are recorded in Figure 5 and include data on the alkaline phosphatase and bilirubin ${ }^{1}$; they show that with the recovery from the disease, all enzyme activities tend to become normal.

Another patient suffering from stricture of the common bile duct and secondary biliary cirrhosis showed the expected change of the enzyme activities only during the first week after operation (Figure 6). From then on, the trend was actually reversed in every instance, including that of the alkaline phosphatase. It may be that these data indicate irreparable damage to the liver parenchyma.

The high tripeptidase activity in the serum of patients with liver disease raised the question

1 We are indebted to Dr. M. H. Power for the use of these data. whether bile itself may contain this enzyme. Table II contains the results of the peptidase test on two specimens of bile which were collected through a $\mathrm{T}$ tube several days after a cholecystectomy and choledochostomy. The conditions of the test were in every respect the same as for serum, and the results are also expressed in p. It is interesting that the tripeptidase activity is very much higher than that of the other peptidases and that the GTy-splitting activity is especially low. This suggests that in cases of obstruction, part of the elevated serum tripeptidase has its origin in the bile. The objection may be raised that some constituents in the bile could have an activating effect on some, an inactivating effect on other peptidases. However, a mixture of serum and bile gave results which appear to be about equal to the sum of the activities of the two constituents when tested individually (Table II).

\section{SUMMARY}

1. The hydrolytic action of serum on glycylglycylglycine, L-leucylglycine, glycyl-L-tyrosine (both manganese-activated) and glycylglycine (cobaltactivated) was studied in a group of normal persons, in patients with liver disease and in patients with a variety of other pathologic conditions.

2. The greatest changes from the normal range were observed in those patients with disease of the liver. The activity of the tripeptidase was

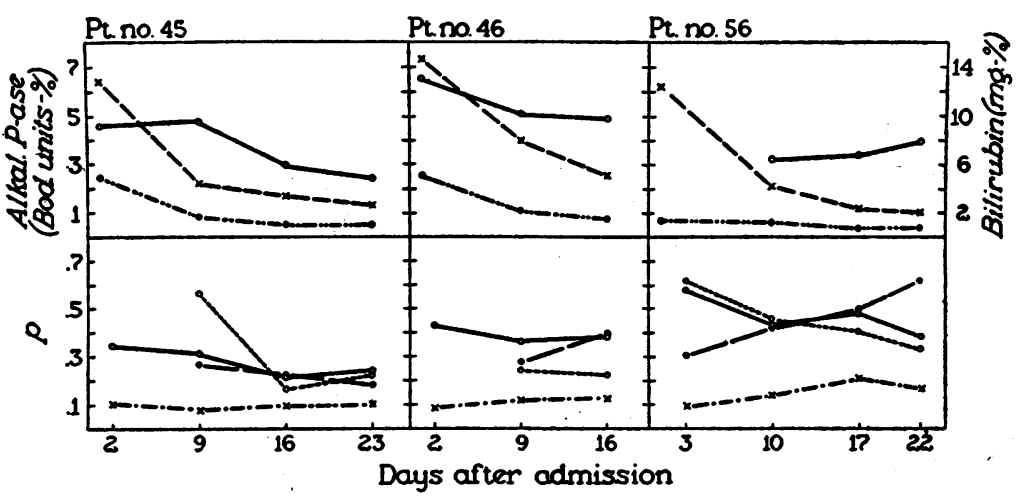

Fig. 5. Serum Peptidase Activity in Acute Infectious Hepatitis Lower part, peptidase activities:

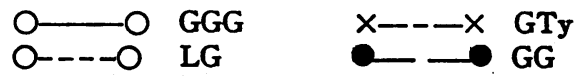

Upper part, alkaline phosphatase $\mathrm{O}-\mathrm{O}$ (normal, 5 units per $100 \mathrm{ml}$.). Bilirubin, direct $\times-\longrightarrow$ (normal : 0 ); indirect $-\ldots$ (normal : less than $0.6 \mathrm{mg}$. per $100 \mathrm{ml}$.). 


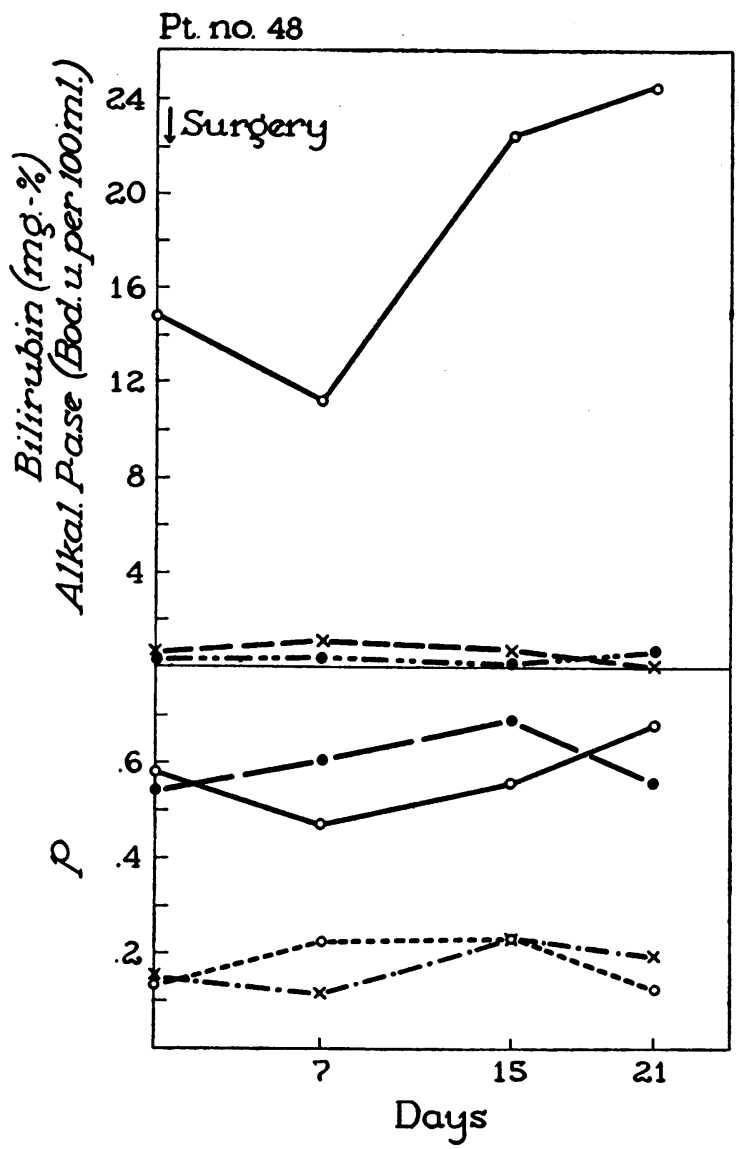

Fig. 6. Serum Peptidase Activity in a Case of Obstructive Jaundice Due to Stricture of the Common DuCT

Lower part, peptidase activities :

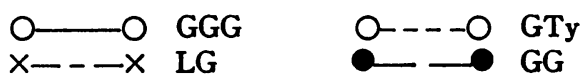

Upper part, alkaline phosphatase $\mathrm{O}-\mathrm{O}$. Bilirubin, direct $X-\longrightarrow$; indirect

usually increased. In external hepatic obstruction and biliary cirrhosis, this increase appeared to be greater than in diseases of the liver parenchyma. The hydrolysis of L-leucylglycine, normally of a very low rate, was studied only in a few patients; it too appeared to be high in liver disease. In contrast, the hydrolysis of glycyl-L-tyrosine and glycylglycine showed a tendency to be low in all conditions affecting the liver.

3. The enzyme activities were followed in three patients with acute infectious hepatitis during the initial period of recovery, and a return toward normal was generally observed. A similar study was undertaken on two patients who underwent operation for obstructive conditions of the bile ducts. In one of these neither the peptidases nor the alkaline phosphatase returned to normal within the period of the study.

4. The analysis of human bile revealed a high tripeptidase activity and a low glycyl-L-tyrosine hydrolyzing power. The activities of the other two enzymes were intermediate.

\section{REFERENCES}

1. Grassmann, W., and Heyde, W., Zur Kenntnis der Peptidasen des Blutserums. Vierte Abhandlung über Enzyme der Leukocyten in der von R. Willstätter und Mitarbeitern begonnenen Untersuchungsreihe. Ztschr. f. physiol. Chem., 1930, 188, 69.

2. Smith, E. L., The specificity of certain peptidases. In Nord, F. F., Advances in Enzymology and Related Subjects of Biochemistry. Interscience Publishers, Inc., New York, 1951, 12, 191.

3. Smith, E. L., The peptidases of skeletal, heart and uterine muscle. J. Biol. Chem., 1948, 173, 553.

4. Stern, Karl, Cullen, Andrea M., and Barber, Virginia T., Peptidase activity in human serum following bone fracture. J. Clin. Investigation, 1949, 28, 419.

5. Cullen, A. M., Barber, V. T., Birmingham, M. K., and Stern, K., Peptidase activity in human serum under various pathological conditions, in pregnancy, and following the administration of ACTH. Canad. J. M. Sci., 1951, 29, 114.

6. Johansen, A., and Thygesen, J. E., The effect of pituitary adrenocorticotropic hormone on human serum peptidase activity. Scandinav. J. Clin. \& Lab. Invest., $1951,3,66$.

7. Smith, E. L., Cartwright, G. E., Tyler, F. H., and Wintrobe, M. M., On the origin of certain serum peptidases as indicated by experimental hemolytic anemia in dogs. J. Biol. Chem., 1950, 185, 59.

8. Fleisher, G. A., Unpublished data.

9. Bamann, Eugen, and Myrbäck, Karl, Die Methoden der Fermentforschung. Leipzig, Georg Thieme, 1941, p. 780.

10. Stern, Karl, Birmingham, Marion K., Cullen, Andrea M., and Richer, Ruth, Peptidase activity in leucocytes, erythrocytes and plasma of young adult and senile subjects. J. Clin. Investigation, 1951, 30, 84.

11. Smith, E. L., and Bergmann, Max, The peptidases of intestinal mucosa. J. Biol. Chem., 1944, 153, 627.

12. Johansen, Arne, and Thygesen, J. E., Direct dilatometry of peptidase activity of normal human serum and hemolysate. Compt. rend. d. trav. du lab. Carlsberg, série chim., 1948, 26, 369.

13. Smith, E. L., Studies on dipeptidases. III. Hydrolysis of methylated peptides; the rôle of cobalt in the 
action of glycylglycine dipeptidase. J. Biol. Chem., 1948, 176, 21.

14. Moore, Stanford, and Stein, W. H., Photometric ninhydrin method for use in the chromatography of amino acids. J. Biol. Chem., 1948, 176, 367.

15. Schwartz, T. B., and Engel, F. L., A photometric ninhydrin method for the measurement of proteolysis. J. Biol. Chem., 1950, 184, 197.

16. Hanger, F. M., The flocculation of cephalin-cholesterol emulsions by pathological sera. Tr. A. Am. Physicians, 1938, 53, 148.

17. Maclagan, N. F., The thymol turbidity test as an in- dicator of liver dysfunction. Brit. J. Exper. Path., 1944, 25, 234.

18. Magath, T. B., The Takata-Ara test of liver function. Am. J. Digest. Dis., 1936, 2, 713.

19. Bodansky, Aaron, Phosphatase studies. II. Determination of serum phosphatase. Factors influencing the accuracy of the determination. J. Biol. Chem., 1933, 101, 93.

20. Powell, W. N., A method for the quantitative determination of serum bilirubin with the photoelectric colorimeter. Am. J. Clin. Path., Tech. Section, 1944, 8, 55. 